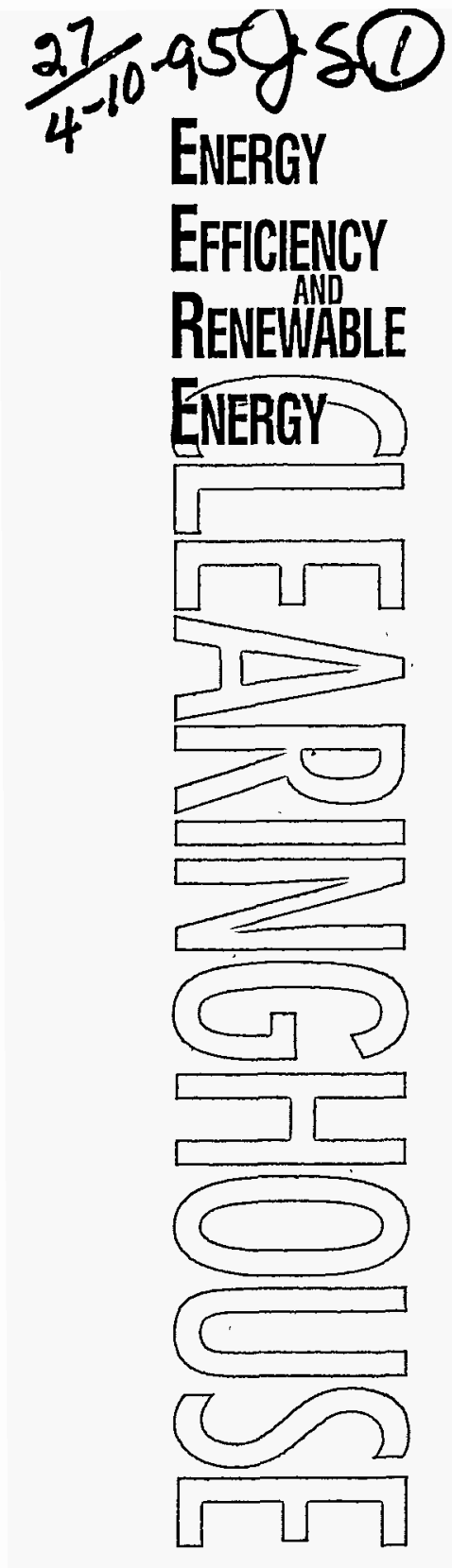

\title{
Cooling Your Home Naturally
}

Keeping cool indoors when it is hot outdoors is a problem. The sun beating down on our homes causes indoor temperatures to rise to uncomfortable levels. Air conditioning provides some relief. But the initial costs of installing an air conditioner and the electricity costs to run it can be high. In addition, conventional air conditioners use refrigerants made of chlorine compounds, suspected contributors to the depletion of the ozone layer and global warming.

But there are alternatives to air conditioning. This publication provides some common sense suggestions and low-cost retrofit options to help you "keep your $\mathrm{cool}^{\prime \prime}$-and save electricity.

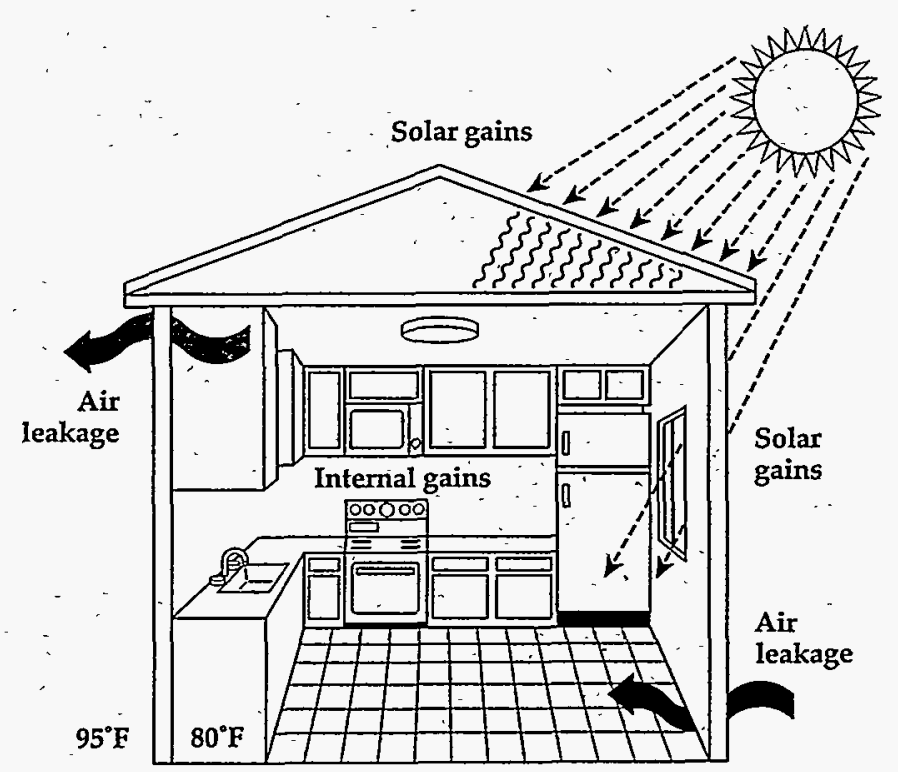

Temperature difference

Four factors affect heat accumulation in a home: solar heat gain, internal heat gain, air leakage, and temperature difference.
BA-A124001

\section{Staying Cool}

An alternative way to maintain a cool house or reduce air-conditioning use is natural (or passive) cooling. Passive cooling uses nonmechanical methods to maintain a comfortable indoor temperature.

The most effective method to cool your home is to keep the heat from building up in the first place. The primary source of heat buildup (i.e., gain) is sunlight absorbed by your house through the roof, walls, and windows. Secondary sources are heat-generating appliances in the home and air leakage.

Specific methods to prevent heat gain include reflecting heat (i.e., sunlight) away from your house, blocking the heat, removing built-up heat, and reducing or eliminating heatgenerating sources in your home.

\section{Reflecting Heat Away}

Dull, dark-colored home exteriors absorb $70 \%$ to $90 \%$ of the radiant energy from the sun that strikes the home's surfaces. Some of this absorbed energy is then transferred into your home by way of conduction, resulting in heat gain. In contrast, lightcolored surfaces effectively reflect most of the heat away from your home.

This document was produced for the U.S. Department of Energy (DOE) by the National Renewable Energy Laboratory (NREL), a DOE national laboratory. The document was produced by the Technical Information Program, under the DOE Office of Energy Efficiency and Renewable Energy. The Energy-Efficiency and Renewable Energy Clearinghouse (EREC) is operated by NCIInformation Systems, Inc., for NREL/DOE. The statements contained herein are based on information known to EREC and NREL at the time of printing. No recommendation or endorsement of any product or service is implied if mentioned by EREC. 


\section{Roofs}

About a third of the unwanted heat that builds up in your home comes in through the roof. This is hard to control with traditional roofing materials. For example, unlike most light-colored surfaces, even white asphalt and fiberglass shingles absorb $70 \%$ of the solar radiation.

home is to keep the

heat from building up

in the first place.

One good solution is to apply a reflective coating to your existing roof. Two stanlocal hardware store or lumberyard. They dard roofing coatings are available at your have both waterproof and reflective properties and are marketed primarily for mobile homes and recreational vehicles.

One coating is white latex that you can apply over many common roofing materials, such as asphalt and fiberglass shingles, tar paper, and metal. Most manufacturers offer a 5-year warranty.

\section{Installing a Radiant Barrier}

Radiant barriers are easy to install. It does not matter which way the shiny surface faces-up or down. But you must install it on the underside of your roofnot horizontally over the ceiling. And the barrier, must face an airspace.

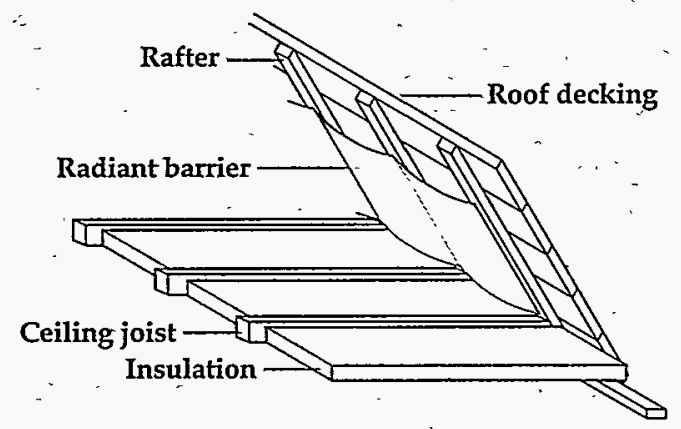

For your own comfort while in the attic, install the radiant barrier on a cool, cloudy day. Use plywood 'walk boards or wooden planks over the ceiling joists for support. Caution: Do not step between the ceiling joists, or you may fall through the ceiling.

Staple the foil to the bottom or side of the rafters, draping it from rafter to rafter. Do not worry about a tight fit or small tears in the fabric; radiant transfer is not affected by air movement. The staples should be no more than 2 to 3 inches ( 5 to 8 centimeters) apart to prevent air circulation from loosening or detaching the radiant barrier.

Use a caulking gun to apply a thin bead of construction adhesive to the rafters along the seams of the foil barrier. This will make the installation permanent.
Radiant-barrier materials cost between $\$ 0.13$ per square foot $(\$ 1.44$ per square meter) for a single-layer product with a kraft-paper backing and $\$ 0.30$ per square foot ( $\$ 3.33$ per square meter) for a vented multilayer product with a fiber-reinforced backing. The latter product doubles as insulation.

\section{Walls}

Wall color is not as important as roof color, but it does affect heat gain somewhat. White exterior walls absorb less heat than dark walls. And light, bright walls increase the longevity of siding, particularly on the east, west, and south sides of the house.

\section{Windows}

Roughly $40 \%$ of the unwanted heat that builds up in your home comes in through windows. Reflective window coatings are one way to reflect heat away from your home. These coatings are plastic sheets treated with dyes or thin layers of metal. Besides keeping your house cooler, these reflective coatings cut glare and reduce fading of furniture, draperies, and carpeting.

Two main types of coatings include suncontrol films and combination films. Suncontrol films are best for warmer climates because they can reflect as much as $80 \%$ of the incoming sunlight. Many of these films are tinted, however, and tend to reduce light transmission as much as they reduce heat, thereby darkening the room.

Combination films allow some light into a room but they also let some heat in and prevent interior heat from escaping. These films are best for climates that have both hot and cold seasons. Investigate the different film options carefully to select the film that best meets your needs. Note: Do not place reflective coatings on southfacing windows if you want to take advantage of heat gain during the winter. 


\section{DISCLAIMER}

This report was prepared as an account of work sponsored by an agency of the United States Government. Neither the United States Government nor any agency thereof, nor any of their employees, make any warranty, express or implied, or assumes any legal liability or responsibility for the accuracy, completeness, or usefulness of any information, apparatus, product, or process disclosed, or represents that its use would not infringe privately owned rights. Reference herein to any specific commercial product, process, or service by trade name, trademark, manufacturer, or otherwise does not necessarily constitute or imply its endorsement, recommendation, or favoring by the United States Government or any agency thereof. The views and opinions of authors expressed herein do not necessarily state or reflect those of the United States Government or any agency thereof. 


\section{DISCLAIMER}

Portions of this document may be illegible in electronic image products. Images are produced from the best available original document. 


\section{Landscaping is a}

natural and

beautiful way to

shade your home and

block the sun.
The coatings are applied to the interior surface of the window. Although you can apply the films yourself, it is a good idea to have a professional install the coatings, particularly if you have several large windows. This will ensure a more durable installation and a more aesthetically pleasing look.

\section{Blocking the Heat}

Two excellent methods to block heat are insulation and shading. Insulation helps keep your home comfortable and saves money on mechanical cooling systems such as air conditioners and electric fans. Shading devices block the sun's rays and absorb or reflect the solar heat.

\section{Insulation}

Weatherization measures-such as insulating, weatherstripping, and caulkinghelp seal and protect your house against the summer heat in addition to keeping out the winter cold. For more information on weatherizing your home, see the Energy Efficiency and. Renewable Energy Clearinghouse (EREC) fact sheet Caulking and Weatherstripping and the U.S. Department of Energy (DOE) fact sheet Insulation.

The attic is a good place to start insulating because it is a major source of heat gain. Adequately insulating the attic protects the upper floors of a house. Recommended attic insulation levels depend on where you live and the type of heating system you use. For most climates, you want a minimum of R-30. In climates with extremely cold winters, you may want as much as R-49. Again, check the DOE fact sheet Insulation on how to determine the ideal level of insulation for your climate.
Wall insulation is not as important for cooling as attic insulation because outdoor temperatures are not as hot as attic temperatures. Allso, floor insulation has little or no effect on cooling.

Although unintentional infiltration of outside air is not a major contributor to inside temperature, it is still a good idea to keep it out. Outside air can infiltrate your home around poorly sealed doors, windows, electrical outlets, and through openings in foundations and exterior walls. Thorough caulking and weatherstripping will control most of these air leaks.

\section{Shading}

Shading your home can reduce indoor temperatures by as much as $20^{\circ} \mathrm{F}\left(11^{\circ} \mathrm{C}\right)$. Effective shading can be provided by trees and other vegetation and exterior or interior shades.

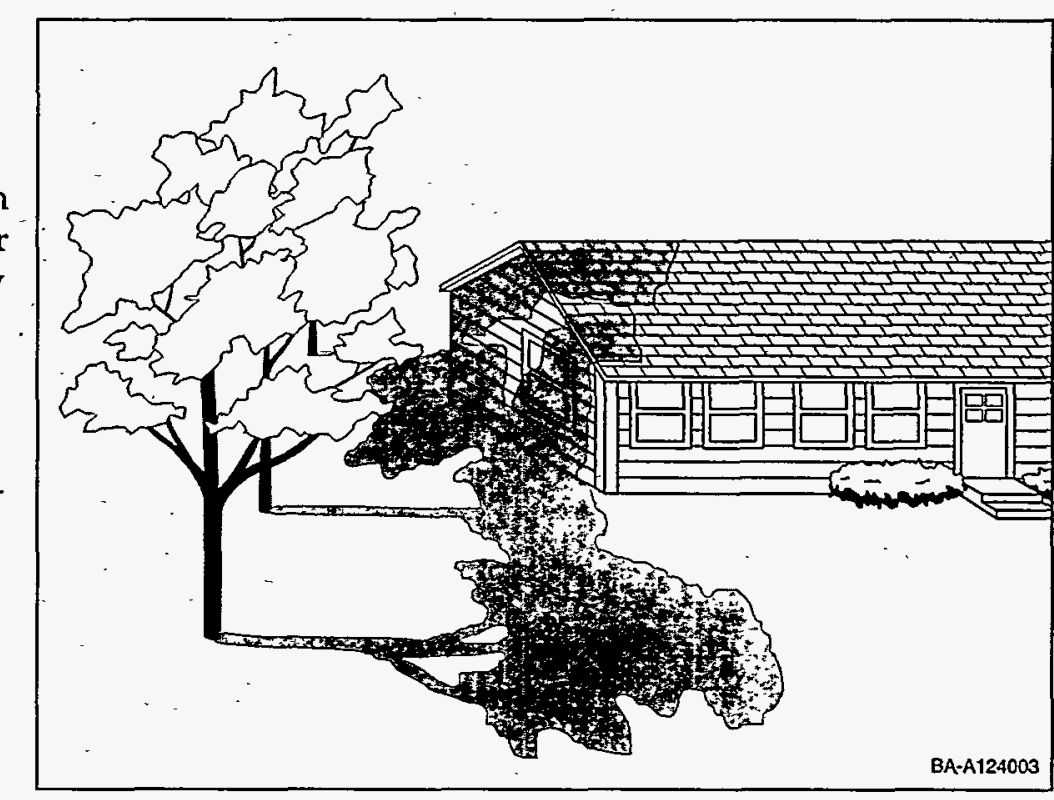

Locate trees to shade the east and west windows and walls. As trees mature, they will shade your roof, too.

\section{Landscaping}

Landscaping is a natural and beautiful way to shade your home and block the sun. A well-placed tree, bush, or vine can deliver effective shade and add to the aesthetic value of your property. When designing your landscaping, use plants native to your area that survive with minimal care. 
Trees that lose their leaves in the fall (i.e., deciduous) help cut cooling energy costs the most. When selectively placed around a house, they provide excellent protection from the summer sun and permit winter sunlight to reach and warm your house. The height, growth rate, branch spread, and shape are all factors to consider in choosing a tree.Vines are a quick way to provide shading and cooling. Grown on trellises, vines can shade windows or the

\section{Planning Your Planting}

Placement of vegetation is important when landscaping your home. The following are suggestions to help you gain the most from vegetation.

- Plant trees on the northeast-southeast and the northwest-southwest sides of your house. Unless you live in a climate where it is hot year-round, do not plant trees directly to the south. Even the bare branches of mature deciduous trees can significantly reduce the amount of sun reaching your house in the winter.

- Plant trees and shrubs so they can direct breezes. Do not place a dense line of evergreen trees where they will block the flow of cool air around or through them.

- Set trellises away from your house to allow air to circulate and keep the vines from attaching to your house's façade and damaging its exterior. Placing vegetation too close to your house can trap heat and make the air around your house even warmer.

- Do not plant trees or large bushes where their roots can damage septic tanks, sewer lines, underground wires, or your house's foundation.

- Make sure the plants you choose can withstand local weather extremes.

whole side of a house. Ask your local nursery which vine is best suited to your climate and needs.

Besides providing shade, trees and vines create a cool microclimate that dramatically reduces the temperature (by as much as $9^{\circ} \mathrm{F}\left[5^{\circ} \mathrm{C}\right]$ ) in the surrounding area. During photosynthesis, large amounts of water vapor escape through the leaves, cooling the passing air. And the generally dark and coarse leaves absorb solar radiation.

You might also consider low ground cover such as grass, small plants, and bushes. A grass-covered lawn is usually $10^{\circ} \mathrm{F}\left(6^{\circ} \mathrm{C}\right)$ cooler than bare ground in the summer. If you are in an arid or semiarid climate, consider native ground covers that require little water. For more information on landscaping, see the EREC fact sheet Landscaping for Energy Efficiency.

\section{Shading Devices}

Both exterior and interior shades control heat gain. Exterior shades are generally more effective than interior shades because they block sunlight before it enters windows. When deciding which devices to use and where to use them, consider whether you are willing to open and close them daily or just put them up for the hottest season. You also want to know how they will affect ventilation.

Exterior shading devices include awnings, louvers, shutters, rolling shutters and shades, and solar screens. Awnings are very effective because they block direct sunlight. They are usually made of fabric or metal and are attached above the window and extend down and out. A properly installed awning can reduce heat gain up to $65 \%$ on southern windows and $77 \%$ on eastern windows. A light-colored awning does double duty by also reflecting sunlight.

Maintaining a gap between the top of the awning and the side of your house helps vent accumulated heat from under a solid-surface awning. If you live in a climate with cold winters, you will want to remove awnings for winter storage, or buy retractable ones, to take advantage of winter heat gain.

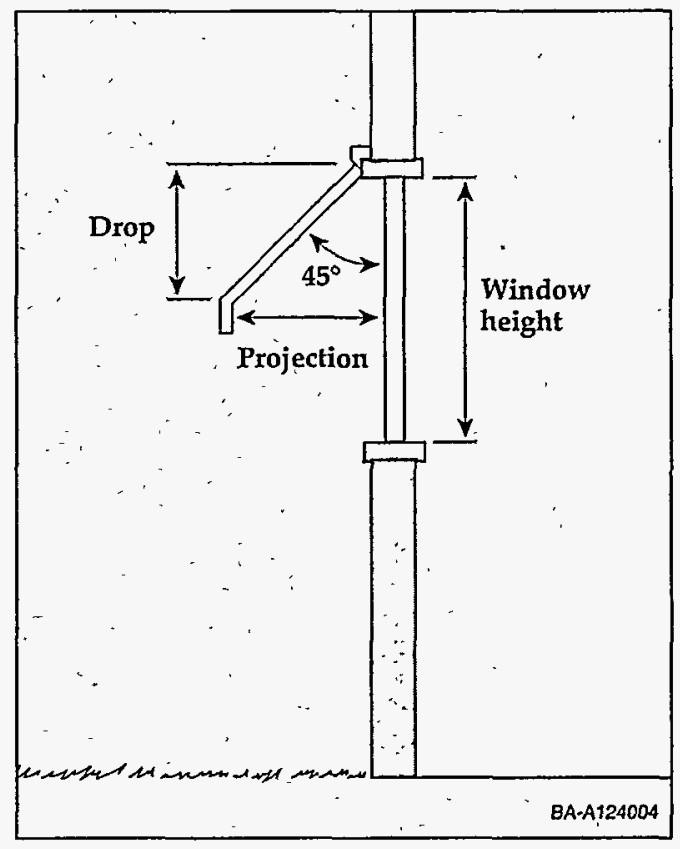

A properly sized awning is an effective exterior shading device. 


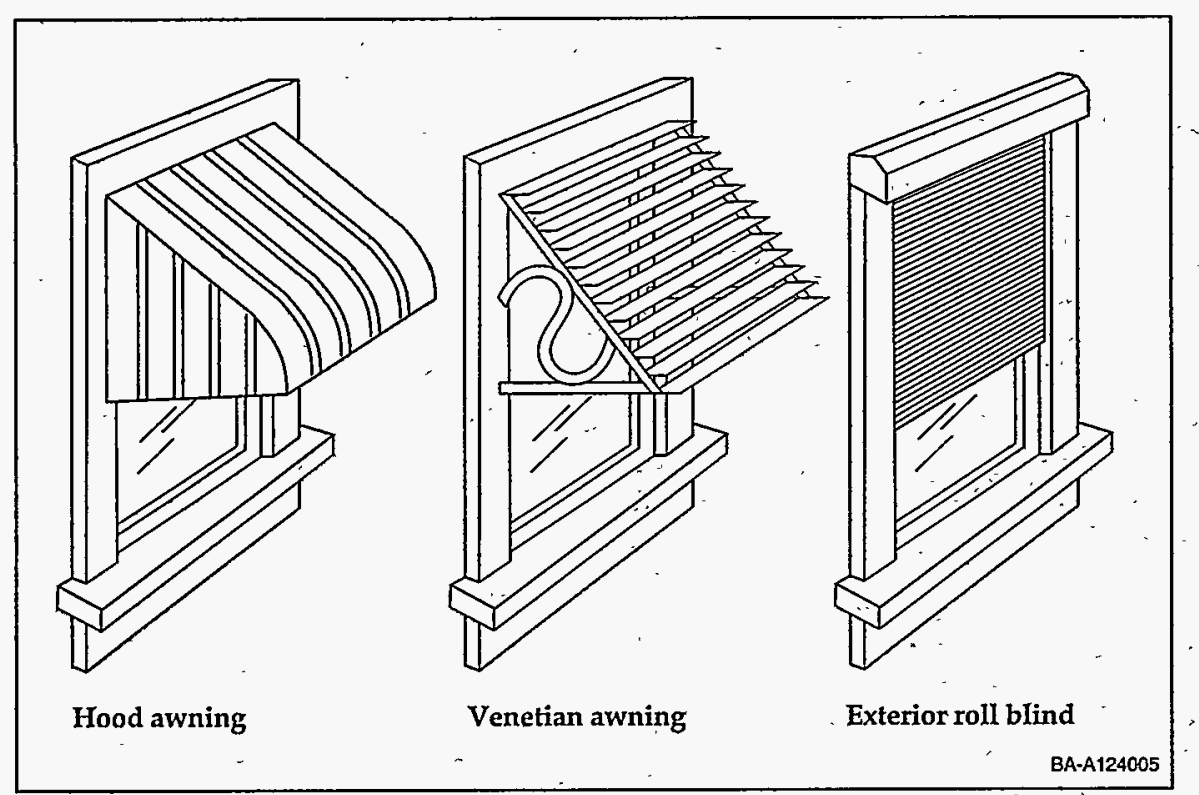

A variety of exterior awning and shade styles are available.

The amount of drop (how far down the awning comes) depends on which side of your house the window is on. An east or west window needs a drop of $65 \%$ to $75 \%$ of the window height. A south-facing window only needs a drop of $45 \%$ to $60 \%$ for the same amount of shade. A pleasing angle to the eye for mounting an awning. is $45^{\circ}$. Make sure the awning does not project into the path of foot traffic unless it is at least 6 feet 8 inches ( 2 meters) from the ground.

One disadvantage of awnings is that they can block views, particularly on the east and west sides. However, slatted awnings do allow limited viewing through the top parts of windows.

Louvers are attractive because their adjustable slats control the level of sunlight entering your home and, depending on the design, can be adjusted from inside or outside your house. The slats can be vertical or horizontal. Louvers remain fixed and are attached to the exteriors of window frames.

Shutters are movable wooden or metal coverings that, when closed, keep sunlight . out. Shutters are either solid or slatted with fixed or adjustable slats. Besides reducing heat gain, they can provide privacy and security. Some shutters hielp insulate windows when it is cold outside.
Rolling shutters have a series of horizontal slats that run down along a track.

Rolling shades use a fabric. These are the most expensive shading options, but they work-well and can provide security. Many exterior rolling shutters or shades can be conveniently controlled from the inside. One disadvantage is that when fully extended, they block all light.

Solar screens resemble standard window screens except they keep direct sunlight from entering the window, cut glare, and block light without blocking the view or eliminating air flow. They also provide privacy by restricting the view of the interior from outside your house. Solar screens come in a variety of colors and screening materials to compliment any home. Although do-it-yourself kits are available, these screens will not last as long as professionally built screens.

Although interior shading is not as effective as exterior shading, it is worthwhile if none of the previously mentioned techniques are possible. There are several ways to block the sun's heat from inside your house.

Draperies and curtains made of tightly - woven, light-colored, opaque fabrics reflect more of the sun's rays than they let through. The tighter the curtain is against the wall around the window, the better it will prevent heat gain. Two layers of draperies improve the effectiveness of the draperies' insulation when it is either hot or cold outside.

Venetian blinds, although not as effective as draperies; can be adjusted to let in some light and air while reflecting the sun's heat. Some newer blinds are coated with reflective finishes. To be effective, the reflective surfaces must face the outdoors.

Some interior cellular (honeycombed) shades also come with reflective mylar coatings. But they block natural light and restrict air flow.

Opaque roller shades are effective when fully drawn but also block light and restrict air flow. 


\section{Ventilated attics}

cooler than

unventilated attics. are about $30^{\circ} \mathrm{F}\left(16^{\circ} \mathrm{C}\right)$

\section{Removing Built-Up Heat}

Nothing feels better on a hot day than a cool breeze. Encouraging cool air to enter your house forces warm air out, keeping your house comfortably cool. However, this strategy only works when the inside temperature is higher than the outside temperature.

Natural ventilation maintains indoor temperatures close to outdoor temperatures and helps remove heat from your home. But only ventilate during the coolest parts of the day or night, and seal off your house from the hot sun and air during the hottest parts of the day.

The climate you live in determines the best ventilation strategy. In areas with cool nights and very hot days, let the night air in to cool your house. A well-insulated house will gain only $1^{\circ} \mathrm{F}\left(0.6^{\circ} \mathrm{C}\right)$ per hour if the outside temperature is $85^{\circ}$ to $90^{\circ} \mathrm{F}$ $\left(29^{\circ}\right.$ to $\left.32^{\circ} \mathrm{C}\right)$. By the time the interior heats up, the outside air should be cooler and can be allowed indoors.

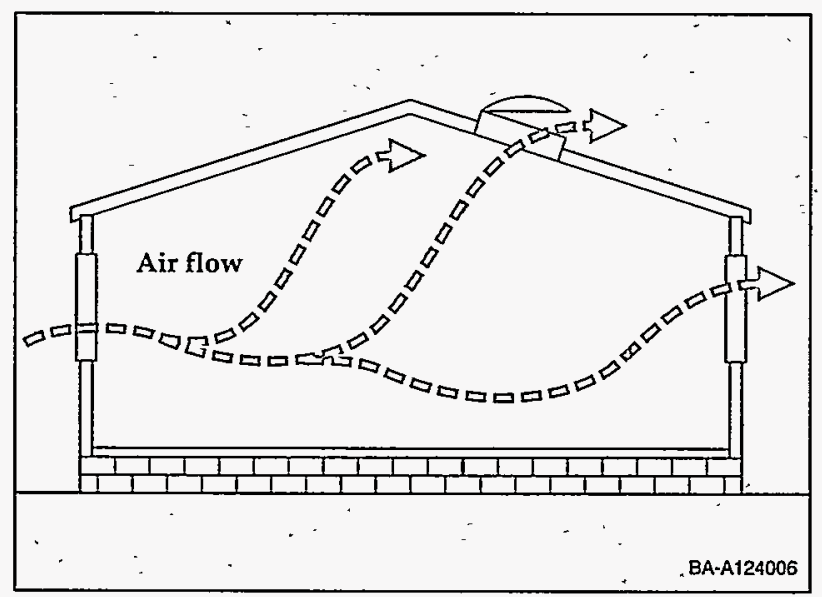

Opening windows at the lowest and highest points in your house creates breezes.

In climates with daytime breezes, open windows on the side from where the breeze is coming and on the opposite side interior doors open to encourage wholeyour location lacks consistent breezes, ing windows at the lowest and highest points in your house.
Ventilating your attic greatly reduces the amount of accumulated heat, which eventually works its way into the main part of your house. Ventilated attics are about $30^{\circ} \mathrm{F}\left(16^{\circ} \mathrm{C}\right)$ cooler than unventilated attics. Properly sized and placed louvers and roof vents help prevent moisture buildup and overheating in your attic. For more information on ventilation, see the EREC fact sheet Fans and Ventilation.

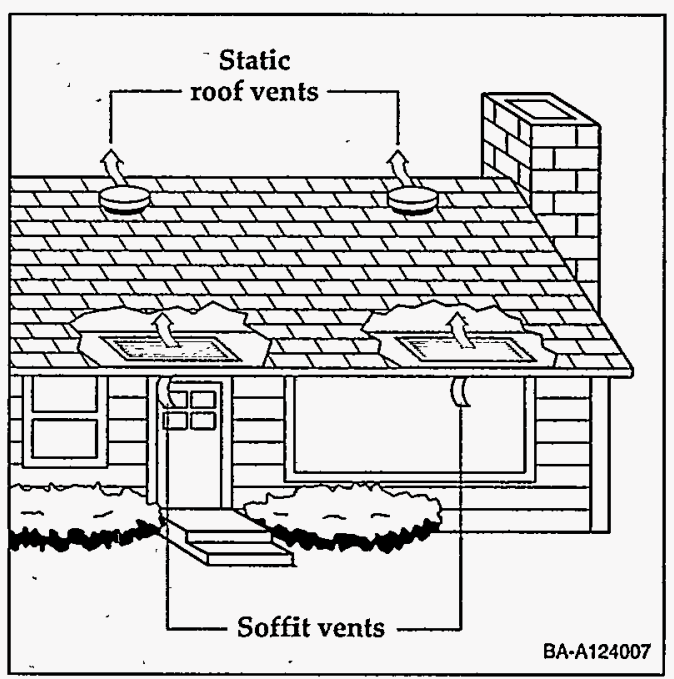

Venting helps keep attics cool. Place intake (soffit) vents low and exhaust (static) vents high.

\section{Reducing Heat-Generating Sources}

Often-overlooked sources of interior heat gain are lights and household appliances, such as ovens, dishwashers, and dryers.

Because most of the energy that incandescent lamps use is given off as heat, use them only when necessary. Take advantage of daylight to illuminate your house. And consider switching to compact fluorescent lamps. These use about $75 \%$ less energy than incandescent lamps, and emit $90 \%$ less heat for the same amount of light. For more information on lighting, see the EREC fact sheet Energy-Efficient Lighting.

In hot, humid climates where temperature swings between day and night are small, ventilate when humidity is not excessive. mosiphoning," or "chimney," effect can be taken a step further by adding a clerestory or a vented skylight. This natural "ther- 
New, energy-

efficient appliances

generate less heat

and use less energy.
Many household appliances generate a lot of heat. When possible, use them in the morning or late evening when you can better tolerate the extra heat. Consider cooking on an outside barbecue grill or use a microwave oven, which does not generate as much heat and uses less energy than a gas or electric range.

Washers, dryers, dishwashers, and water heaters also generate large amounts of heat and humidity. To gain the most benefit, seal off your laundry room and water heater from the rest of the house.

New, energy-efficient appliances generate less heat and use less energy. When it is time to purchase new appliances, make sure they are energy efficient. All refrigerators, dishwashers, and dryers display an EnergyGuide label indicating the annual estimated cost for operating the appliance or a standardized energy efficiency ratio. Compare appliances and buy the most efficient models for your needs. For more information, see the EREC fact sheet $A$ Guide to Making Energy-Smart Purchases.

\section{Saving Energy}

Using any or all of these strategies will help keep you cool. Even if you use air conditioning, many of these strategies, particularly reflecting heat and shading, will help reduce the energy costs of running an air conditioner.

However, adopting all of these strategies may not be enough. Sometimes you need to supplement natural cooling with mechanical devices. Fans and evaporative coolers can supplement your cooling strategies and cost less to install and run than air conditioners.

Ceiling fans make you feel cooler. Their effect is equivalent to lowering the air temperature by about $4^{\circ} \mathrm{F}\left(2^{\circ} \mathrm{C}\right)$. Evaporative coolers use about one-fourth the energy of conventional air conditioners.

Many utility companies offer rebates and other cost incentives when you purchase or install energy-saving products, such as insulation and energy-efficient lighting and appliances. Contact your local utility company to see what it offers in the way of incentives.

\section{Cooling Strategies Checklist}

\begin{tabular}{|l|l|l|}
\hline \multicolumn{1}{|c|}{ Cooling Strategies To Consider } & Cost (\$) & Action: Yes/No \\
\hline Lighten roof and exterior wall color & & \\
\hline Replace/coat roof with bright white or shiny material & & \\
\hline Install a radiant barrier & & \\
\hline Add reflective coatings to windows & & \\
\hline Insulate attic and walls & & \\
\hline Caulk and weatherstrip to seal air leaks & & \\
\hline Add shade trees, bushes, or vines & & \\
\hline Add exterior awnings and shades & & \\
\hline Add interior drapes and shades & & \\
\hline Ventilate attic & & \\
\hline Increase natural ventilation & & \\
\hline Isolate heat-generating appliances & & \\
\hline Replace heat-generating appliances & & \\
\hline Replace light bulbs with energy-efficient fluorescents & & \\
\hline
\end{tabular}




\section{Source List}

There are hundreds of groups that can provide you with more information on natural cooling strategies. The following organizations are just a few that can assist you in keeping your cooling costs down.

\section{American Council for an Energy-Efficient Economy}

(ACEEE)

1001 Connecticut Avenue, NW, Suite 801

Washington, DC 20036

(202) 429-8873

ACEEE provides general and technical information on energy efficiency.

\section{American Solar Energy Society (ASES) \\ 2400 Central Avenue, Unit G-1 \\ Boulder, CO 80301 \\ (303) 443-3130}

ASES is a professional society that fosters the exchange of information about solar energy technologies.

Florida Solar Energy Center (FSEC)

300 State Road 401

Cape Canaveral, FL 32920

(407) 783-0300

FSEC is a research and education center that provides technical services and information on passive cooling strategies for hot and humid climates.

\section{Passive Solar Industries Council (PSIC)}

1511 K Street, NW, Suite 600

Washington, DC 20005

(202) 628-7400

PSIC provides practical information on energy-conscious, passive solar design and construction to the U.S. building industry.

For information about these energy efficiency topics, contact:

The Energy Efficiency and Renewable Energy

Clearinghouse (EREC)

P.O. Box 3048

Merrifield, VA 22116

(800) 363-3732

EREC provides free general and technical information to the public on the many topics and technologies pertaining to energy efficiency and renewable energy.

You may also contact your state and local energy offices as well as your local solar energy association for regional-specific information on natural cooling.

\section{Reading List}

The following publications provide further information on natural or passive cooling. This list does not cover all the available books, reports, and articles on passive cooling, nor is the mention of any publication a recommendation or endorsement.

To obtain the publications in this bibliography, contact your local library, bookstore, or the publisher. Check the prices through your bookstore or the publisher before placing an order.

\section{Books, Pamphlets, and Reports}

Cooling Our Communities: A Guidebook on Tree Planting and Light-Colored Surfacing, Government Printing Office, Stock No. 055-000-00371-8, 1992.

Insulation, available from EREC (see Source List), DOE/CE-0180, 1988.

Landscape Planning for Energy Conservation, G.O. Robinette and C. McClennon (eds.), Van Nostrand Reinhold Co., 1983.

Low Energy Cooling, D. Abrams, Van Nostrand Reinhold Co., 1986.

"Measured Cooling Savings from Vegetative Landscaping," A. Meier, Proceedings of 1990 Summer Study on Energy Efficiency in Buildings, available from ACEEE (see Source List), pp. 4.133-4.144, 1990.

"Measured Savings in Air Conditioning from Shade Trees \& White Surfaces," H. Akbari et al., Proceedings of ACEEE 1992 Summer Study on Energy Efficiency in Buildings, available from ACEEE (see Source List), pp. 9.1-9.10, 1992.

Radiant Barriers: $A$ Question and Answer Primer, I. Melody, available from FSEC (see Source List), Report No. FSEC-EN-15-87, 1987.

Your Home Cooling Energy Guide, J. Krigger, Saturn Resource Management, 324 Fuller Avenue, S-8, Helena, MT 59601, 1991.

\section{Articles}

"A Comparison of Passive Cooling Techniques," G.N. Tiwari, M. Upadhyay, and S.N. Rai, Building and Environment, (29:1) p. 21, 1994.

"Home Cooling Strategies," Consumers Digest, (31:38) p. 2, May/June 1992.

"Keeping Cool: Natural Cooling and Air Conditioning," D. Johnson, Family Handyman, (40:3) p. 30, September 1990.

"Passive Cooling in a Hot, Arid Climate," H.W. Arch, Solar Today, (5:2) pp. 15-17, March/April 1991.

"Strategic Planting," Energy Auditor \& Retrofitter, A. Meier and J. Friesen, (4:4) pp. 7-12, July/August 1987. 